\title{
Upaya meningkatkan kemampuan guru dalam penggunaan metode pembelajaran melalui supervisi klinis di SD Negeri 29 Ganting
}

\author{
Heni Jasnita \\ SDN 29 Ganting Kecamatan Bayang
}

\begin{abstract}
Abstrak
Metode pembelajaran merupakan salah satu komponen yang sangat mempengaruhi keberhasilan kegiatan belajar mengajar, karena di dalamnya memuat strategi agar anak didik dapat belajar secara efektif dan esifien. Berkaitan dengan pelaksanaan kegiatan supervisi klinis di SD Negeri 29 Ganting Kecamatan Bayang Kabupaten Pesisir Selatan, target yang diharapkan adalah kemampuan guru dalam menggunakan metode pembelajaran dengan asumsi bahwa melalui penerapan metode yang tepat maka proses ekplorasi, elaborasi dan konfirmasi dalam kegiatan inti pembelajaran dapat dioptimalkan sehingga prestasi belajar siswa menjadi meningkat. Peningkatan kemampuan guru dalam menggunakan metode pembelajaran melalui supervisi klinis merupakan salah satu solusi yang cukup efektif. Hal tersebut dapat dilihat dari hasil akhir penelitian dimana guru dapat menguasai indikator yang ada dalam menentukan metode pembelajaran dan mencari metode yang benar-benar tepat dan sesuai dengan tujuan pembelajaran serta kondisi lingkungan kelas dan lingkungan sekolah itu sendiri yang selanjutnya memberikan manfaat bagi peningkatan prestasi belajar siswa dan peningkatan mutu sekolah.
\end{abstract}

Keywords: kemampuan guru, metode pembelajaran superbisi klinis

\section{PENDAHULUAN}

Pendidikan adalah sebagai usaha sadar dan terencana untuk mewujudkan suasana belajar dan proses pembelajaran untuk peserta didik secara aktif mengembangkan potensi dirinya untuk memiliki kekuatan spiritual keagamaan, pengendalian diri, kepribadian, kecerdasan, akhlak mulia, serta keterampilan yang diperlukan dirinya dan masyarakat. Pengertian Pendidikan dapat diartikan sebagai usaha sadar dan sistematis untuk mencapai taraf hidup atau untuk kemajuan lebih baik. Secara sederhana, Pengertian pendidikan adalah proses pembelajaran bagi peserta didik untuk dapat mengerti, paham, dan membuat manusia lebih kritis dalam berpikir.

Dalam era globalisasi dimana persaingan semakin ketat di segala bidang kehidupan, tidak ada alternatif lain selain berupaya meningkatkan sumber daya manusia yang ada melalui upaya peningkatan mutu pendidikan di setiap jenjang pendidikan. Keberhasilan peningkatan mutu pendidikan, tentu tidak bisa dilepaskan dari keberadaan seorang guru. 
Guru adalah pendidik profesional dengan tugas utama mendidik, mengajar, membimbing, mengarahkan, melatih, menilai, dan mengevaluasi peserta didik pada pendidikan anak usia dini jalur pendidikan formal, pendidikan dasar, dan pendidikan menengah.(Peraturan Pemerintah No 74 tahun 2008 tentang guru dan dosen)

Guru sebagai pendidik dan pengajar merupakan salah satu faktor penentu keberhasilan setiap upaya pendidikan. Pada setiap inovasi pendidikan khususnya dalam perubahan kurikulum dan peningkatan sumber daya manusia yang dihasilkan dari upaya pendidikan selalu saja bermuara pada guru. Hal ini menunjukkan betapa eksisnya peran guru dalam dunia pendidikan.

Guru memiliki posisi yang sangat penting dan menentukan keberhasilan pendidikan. Guru berada pada lini paling depan dalam keterlaksanaan proses pembelajaran di sekolah. Guru merupakan orang yang paling bertanggung jawab atas kualitas dan kebermaknaan proses pembelajaran di dalam kelas. Oleh karena itu, kinerja guru sangat berpengaruh terhadap keberhasilan sebuah proses pembelajaran.

Peraturan Menteri Pendidikan Nasional No. 16 Tahun 2007 tentang Standar Kualifikasi Akademik dan Kompetensi Guru, diharapkan kinerja guru semakin meningkat dan baik. Dalam kaitan dengan proses belajar mengajar hendaknya guru dapat mengarahkan dan membimbing siswa untuk aktif dalam kegiatan belajar mengajar sehingga tercipta suatu interaksi yang baik antara guru dengan siswa maupun siswa dengan siswa. Hal ini senada juga ditulis Madri M dan Rosmawati, bahwa terjadinya proses pembelajaran itu ditandai dengan dua hal yaitu : (1) siswa menunjukkan keaktifan, seperti tampak dalam jumlah curahan waktu untuk melaksanakan tugas ajar, (2) terjadi perubahan perilaku yang selaras dengan tujuan pengajaran yang diharapkan (2004).

Pada kenyataannya dari hasil temuan di lapangan masih banyak guru yang belum mampu menerapkan metode-metode pembelajaran dengan baik. Kondisi tersebut juga terjadi di di SD Negeri 29 Ganting Kecamatan Bayang Kabupaten Pesisir Selatan . Dari 8 (delapan) guru, 6 (enam) orang diantaranya selalu menggunakan metode pembelajaran dengan metode ceramah, tanya jawab, diskusi dan diakhiri dengan pemberian tugas. Pemberian materi juga lebih terpusat pada guru. Kemampuan guru dalam mengembangkan strategi pembelajaran melalui pemilihan metode, media, alat peraga, maupun sumber belajar belum optimal. Dengan kondisi demikian, jika dibiarkan maka akan menghambat proses pembelajaran dimana hasil belajar tidak akan dicapai dengan maksimal.

Tugas guru adalah mendiagnosis kebutuhan belajar, merencanakan pelajaran, memberikan presentasi, mengajukan pertanyaan, dan mengevaluasi pengajaran. Pengelolaan kelas yang efektif merupakan prasyarat yang kritis bagi kegiatan intruksional yang efektif agar seorang guru berhasil mengelola kelas hendaklah ia mampu mengantisipasi tingkah laku siswa yang salah dan mencegah tingkah laku demikian agar tidak terjadi.

Berdasarkan hal di atas sudah seharusnya dalam proses belajar mengajar seorang guru mampu memilih dan menggunakan metode pembelajaran yang sesuai, agar siswa dapat belajar secara efektif dan efisien sesuai tujuan yang diharapkan. Peranan guru dalam menentukan metode pembelajaran sangatlah penting, sehingga guru hanya sebagai fasilitator saja. Kondisi tersebut tentu menjadi keprihatinan tersendiri bagi penulis sebagai kepala sekolah. Oleh karena itu, pada tahap awal peneliti yang sekaligus kepala sekolah di SD Negeri 29 Ganting Kecamatan Bayang Kabupaten Pesisir Selatan berupaya melakukan upaya pendekatan dengan sesama guru melalui perbincangan untuk mengetahui hal-hal yang menjadi kendala oleh guru dalam memilih metode pembelajaran yang tepat dan sesuai dengan pembelajaran.

Dari hasil wawancara tersebut, dihasilkan suatu kesimpulan bahwa kesulitan guru dalam memilih metode didasari oleh sulitnya menentukan materi dengan kegiatan pembelajaran yang tepat. Selain itu kondisi siswa yang motivasinya rendah menjadi kendala tersendiri dalam mengaplikasikan metode pembelajaran tertentu pembelajaran yang belum memenuhi semua kebutuhan pembelajaran.

Mengacu pada hasil di atas, maka guru dan peneliti melakukan kesepakatan untuk memperbaiki kondisi yang ada melalui kegiatan supervisi yaitu supervisi klinis. Supervisi klinis adalah suatu proses bimbingan yang bertujuan untuk membantu pengembangan professional guru/calon guru, khususnya dalam penampilan mengajar, berasarkan observasi dan analisis data secara teliti dan objektif sebagai pegangan untuk perubahan tingkat laku mengajar tersebut (John J. Bolla dalam Ngalim Purwanto 2009). Dengan adanya pelaksanaan supervisi oleh kepala sekolah diharapkan member dampak terhadap terbentuknya sikap professional guru.

Bertitik tolak dari uraian di atas maka penulis tertarik untuk mengadakan Penelitian Tindakan Sekolah dengan judul "Upaya Meningkatkan Kemampuan Guru dalam Penggunaan Metode Pembelajaran Melalui 
Supervisi Klinis di SD Negeri 29 Ganting Kecamatan Bayang Kabupaten Pesisir Selatan Tahun Pelajaran 2017/2018”.

\section{METODE}

SD Negeri 29 Ganting Kecamatan Bayang Kabupaten Pesisir Selatan merupakan salah satu sekolah negeri yang berada di wilayah Kecamatan Bayang Kanbupaten Pesisir Selatan yang secara geografis terletak di daerah pedesaan tidak terlalu jauh dari pusat kecamatan. Perkembangan pendidikan di SD Negeri 29 Ganting Kecamatan Bayang Kabupaten Pesisir Selatan secara umum tidak ketinggalan dengan sekolah-sekolah lain. SD Negeri 29 Ganting Kecamatan Bayang Kabupaten Pesisir Selatan terbagi dalam 6 rombongan belajar. Jumlah guru yang mengajar saat ini sebanyak 9 orang sudah termasuk guru PAI, Pendidikan Al Qur'an dan guru Olah Raga (Penjaskes).

Subyek yang diteliti pada pelaksanaan Penelitian Tindakan Sekolah ini, adalah sebagai berikut:kepala sekolah (dirinya sendiri), guru kelas IV, V, dan VI yaitu : Guru kelas IV (Sdri.Susmai Sasrita,S.Pd), guru kelas V (Sdri.Jasni,S.Pd.SD), dan guru kelas VI (Asnati, S.Pd), dan siswa. Tindakan yang dilakukan untuk meningkatkan kemampuan guru dalam mengguakan metode pembelajaran pada guru kelas IV, V, dan VI adalah melalui Penelitian Tindakan Sekolah (PTS) melalui teknik supervisi klinis.

Langkah-langkah yang digunakan sebagai prosedur penelitian tindakan, mengacu pada pendapat yang dikemukakan oleh Kemmis dan M. Taggart, dengan menggunakan model spiral. Langkah-langkah tersebut meliputi: perencanaan (planning), pelaksanaan (action), observasi (observing), dan refleksi (reflection).

Tindakan dalam penelitian ini adalah melaksanakan proses supervisi berdasarkan skenario yang sudah dirancang yaitu upaya peningkatan kemampuan guru dalam penggunaan metode pembelajaran. Indikator keberhasilan pada tahap ini adalah guru meningkat kemampuannya.

Tujuan untuk memperoleh objektif tentang situasi pembelajaran, kesulitan guru, perbaikan proses pembelajaran. Saat kegiatan supervisi berlangsung peneliti melakukan pengamaan dengan menggunakan lembar pengamatan atau observasi yang bertujuan untuk memperoleh gambaran aktivitas dari guru dan kreativitas guru dalam menentukan metode pembelajaran. Saat proses supervisi berlangsung peneliti melakukan pengamatan kembali terhadap penggunaan metode pembelajaran untuk memperoleh gambaran tentang kemampuan guru dalam penentuan metode pembelajaran dan aktivitas siswa dalam mengikuti kegiatan belajar mengajar untuk memperoleh hasil yang optimal. Teknik yang digunakan untuk mengumpulkan data meliputi observasi, wawancara, dan dokumentasi yang masing-masing secara singkat diuraikan sebagai berikut: Teknik analisis data dilakukan dengan melakukan analisis SWOT, yang terdiri dari unsur-unsur S-Strength (kekuatan), WWeaknesses (kelemahan), O-Opportuniy (kesempatan), T-Threat (ancaman). Empat hal tersebut dilihat dari sudut kepala sekolah yang melaksanakan dan guru yang dikenai tindakan (Suharsimi Arikunto, 2008).

Melalui penerapan teknik analisis SWOT, kekuatan dan kelemahan yang ada pada diri peneliti dan subjek tindakan diidentifikasi secara cermat sebelum mengidentifikasi yang lain. Unsur kesempatan dan ancaman diidentifikasi dari luar peneliti dan juga luar dini guru (subyek yang dikenai tindakan). Melalui pemanfaatan unsur ini, peneliti mempertimbangkan faktor dari luar peneliti sendiri maupun guru sebagai subyek tindakan yang bisa dimanfaatkan dan dipertimbangkan karena bisa memberikan dampak yang kurang baik terhadap tindakan tanpa harus mengubah situasi asli yang tidak mengandung resiko.

\section{HASIL PENELITIAN}

\section{Siklus I}

Dari hasil pengamatan terhadap kemampuan guru dalam menggunakan metode pembelajaran pada pelaksanaan pembelajaran mata pelajaran bahasa Indonesia dengan tujuan agar siswa dapat melengkapi cerita dengan memperhatikan hubungan antara makna kalimat yang satu dengan kalimat lainnya dan siswa dapat menentukan judul yang sesuai berdasarkan gambar seri hasilnya masih dalam kategori "kurang" dengan nilai 2,55 karena berada dalam interval score yaitu 2,38 - 2,77. Dari data di atas, ternyata dalam kegiatan pembelajaran guru belum mengaplikasikan seluruh metode yang tercantum dalam RPP. Pendekatan inkuiri yang tercantum dalam RPP belum dioptimalkan. 
Tabel 1. Hasil Pengamatan Terhadap Kemampuan Guru Kelas IV dalam Menggunakan Metode Pembelajaran (Siklus I)

\begin{tabular}{|c|c|c|c|c|c|}
\hline \multirow[t]{2}{*}{ No } & \multirow[t]{2}{*}{ Indikator } & \multicolumn{4}{|c|}{ Nilai } \\
\hline & & 1 & 2 & 3 & 4 \\
\hline 1 & $\begin{array}{l}\text { Kesesuaian antara metode dengan tujuan pembelajaran } \\
\text { Kesesuaian metode dengan materi }\end{array}$ & - & - & $\mathrm{V}$ & - \\
\hline 2 & Metode dapat memotivasi belajar siswa & - & $\mathrm{V}$ & - & - \\
\hline 3 & Metode dapat melibatkan siswa dalam pembelajaran & - & - & $\mathrm{V}$ & - \\
\hline 4 & $\begin{array}{l}\text { Metode dapat mengefektifkan kegiatan pembelajaran } \\
\text { Metode yang digunakan dapat meningkatkan hasil }\end{array}$ & - & $\mathrm{V}$ & - & - \\
\hline 5 & belajar siswa & - & - & $\mathrm{V}$ & - \\
\hline 6 & & - & V & - & - \\
\hline \multicolumn{2}{|c|}{ Jumlah } & 0 & 6 & 9 & 0 \\
\hline \multicolumn{2}{|c|}{ Rata-rata } & \multicolumn{4}{|c|}{2,55} \\
\hline
\end{tabular}

\begin{tabular}{|c|c|c|}
\hline \multicolumn{3}{|c|}{ Keterangan score: } \\
\hline A & $3,28-4,00$ & : Sangat Memuaskan \\
\hline B & $: 2,78-3,27$ & : Memuaskan \\
\hline $\mathrm{C}$ & $: 2,38-2,77$ & : Kurang \\
\hline
\end{tabular}

Tabel 2. Hasil Pengamatan Terhadap Kemampuan Guru Kelas V dalam Menggunakan Metode Pembelajaran (Siklus I)

\begin{tabular}{|c|c|c|c|c|c|}
\hline \multirow[t]{2}{*}{ No } & \multirow[t]{2}{*}{ Indikator } & \multicolumn{4}{|c|}{ Nilai } \\
\hline & & 1 & 2 & 3 & 4 \\
\hline 1 & $\begin{array}{l}\text { Kesesuaian antara metode dengan tujuan } \\
\text { pembelajaran }\end{array}$ & - & - & $\mathrm{V}$ & - \\
\hline \multirow[t]{2}{*}{2} & $\begin{array}{l}\text { Kesesuaian metode dengan materi } \\
\text { Metode dapat memotivasi belajar siswa }\end{array}$ & - & V & - & - \\
\hline & Metode dapat melibatkan siswa dalam pembelajaran & - & - & $\mathrm{V}$ & - \\
\hline 4 & $\begin{array}{l}\text { Metode dapat mengefektifkan kegiatan pembelajaran } \\
\text { Metode yang digunakan dapat meningkatkan hasil } \\
\text { belajar siswa }\end{array}$ & - & - & $\mathrm{V}$ & - \\
\hline \multicolumn{6}{|l|}{5} \\
\hline & & - & - & V & - \\
\hline \multicolumn{2}{|c|}{ Jumlah } & 0 & 4 & 12 & 0 \\
\hline \multicolumn{2}{|c|}{ Rata-rata } & \multicolumn{4}{|c|}{2,67} \\
\hline
\end{tabular}

\section{Keterangan score:}

$\begin{array}{lll}\text { A } & : 3,28-4,00 & : \text { Sangat Memuaskan } \\ \text { B } & : 2,78-3,27 & : \text { Memuaskan } \\ \text { C } & : 2,38-2,77 & : \text { Kurang }\end{array}$

Mengacu hasil pengamatan terhadap kemampuan guru kelas $\mathrm{V}$ dalam menggunakan metode pembelajaran pada pelaksanaan pembelajaran mata pelajaran bahasa Indonesia dengan tujuan: (1) siswa dapat mengembangkan ide pokok dalam membuat karangan cerita yang sesuai dengan pengalamannya sendiri melalui bantuan media gambar bingkai, dan (2) siswa dapat mengarang cerita secara lebih mudah dengan menggunakan pilihan kata yang tepat atau sesuai, susunan kalimat yang runtut dengan memperhatikan ejaan yang benar, kemampuan guru dalam menggunakan metode pembelajaran masih "kurang”, dengan nilai rata-rata 2,67. 
Tabel 3. Hasil Pengamatan Terhadap Kemampuan Guru Kelas VI dalam Menggunakan Metode Pembelajaran (Siklus I)

\begin{tabular}{|c|c|c|c|c|c|}
\hline \multirow[t]{2}{*}{ No } & \multirow[t]{2}{*}{ Indikator } & \multicolumn{4}{|c|}{ Nilai } \\
\hline & & $\mathbf{1}$ & 2 & 3 & $\overline{4}$ \\
\hline 1 & $\begin{array}{l}\text { Kesesuaian antara metode dengan tujuan } \\
\text { pembelajaran }\end{array}$ & - & - & V & - \\
\hline 2 & Kesesuaian metode dengan materi & - & $\mathrm{V}$ & - & - \\
\hline 3 & Metode dapat memotivasi belajar siswa & & & & \\
\hline 4 & $\begin{array}{l}\text { Metode dapat melibatkan siswa dalam } \\
\text { pembelajaran }\end{array}$ & - & $\mathrm{V}$ & - & - \\
\hline 5 & $\begin{array}{l}\text { Metode dapat mengefektifkan kegiatan } \\
\text { pembelajaran }\end{array}$ & - & $\mathrm{V}$ & - & - \\
\hline & $\begin{array}{l}\text { Metode yang digunakan dapat meningkatkan } \\
\text { hasil belajar siswa }\end{array}$ & - & $\mathrm{V}$ & - & - \\
\hline 6 & & - & - & $\mathrm{V}$ & - \\
\hline Jum & & 0 & 8 & 8 & - \\
\hline Rata & ata & & & & \\
\hline
\end{tabular}

\begin{tabular}{|c|c|}
\hline \multicolumn{2}{|l|}{ Keterangan score: } \\
\hline$: 3,28-4,00$ & : Sangat Memuaskan \\
\hline$: 2,78-3,27$ & : Memuaskan \\
\hline$: 2,38-2,77$ & : Kurang \\
\hline
\end{tabular}

Mengacu hasil pengamatan terhadap kemampuan guru kelas VI dalam menggunakan metode pembelajaran pada pelaksanaan pembelajaran mata pelajaran matematika, kemampuan guru dalam menggunakan metode pembelajaran masih "kurang", dengan nilai rata-rata 2,67.

\section{Refleksi}

Dari hasil pelaksanaan supervisi klinis pada upaya peningkatan kemampuan guru dalam menggunakan metode pembelajaran diketahui bahwa pada siklus I, guru sudah berusaha untuk meningkatkan kemampuannya dalam mengunakan metode pembelajaran.

Dari hasil observasi di kelas IV diketahui bahwa guru belum menerapkan seluruh metode yang terdapat dalam RPP. Selain itu pelaksanaan kegiatan pembelajaran juga masih membutuhkan metode yang tepat dan sesuai dengan tujuan pembelajaran, sehingga diperlukan adanya diskusi antara peneliti (kepala sekolah) dengan guru agar secara bersama-sama dapat mengatasi permasalahan yang ada.

Dari hasil observasi di kelas V diketahui bahwa metode konstruktivisme dan inquiri yang tercantum dalam RPP belum diterapkan ketika pelaksanaan pembelajaran. Dari temuan tersebut maka diperlukan suatu keterbukaan dari guru untuk mendiskusikan kealpaan tersebut dilatarbelakangi oleh masalah apa (misalnya : ketidakmampuan guru/keterbatasan waktu, dan sebagainya) sehingga dapat dipecahkan secara bersama-sama masalah yang ada

Dari hasil observasi di kelas VI guru juga belum menguasai seluruh indikator yang dinilai selama kegiatan supervisi klinis. Metode pembelajaran yang tercantum dalam RPP juga belum dioptimalkan karena ada satu metode yang terlewat yaitu tugas individual. Selain temuan-temuan tersebut, guru juga belum menerapkan metode yang baru yang benar-benar dapat melibatkan siswa secara aktif dalam kegiatan pembelajaran dan mampu memotivasi siswa untuk belajar matematika.

Dari temuan-temuan yang ada, maka diperlukan adanya upaya perbaikan untuk meninkatkan kemampuan guru dalam menggunakan metode pembelajaran sehingga penelitian tindakan sekolah dengan menerapkan pendekatan supervisi klinis harus dilanjutkan lagi pada siklus kedua. 


\section{Siklus II}

Tabel 4. Hasil Pengamatan Terhadap Kemampuan Guru Kelas IV dalam Menggunakan Metode Pembelajaran (Siklus II)

\begin{tabular}{|c|c|c|c|c|c|}
\hline \multirow[t]{2}{*}{ No } & \multirow[t]{2}{*}{ Indikator } & \multicolumn{4}{|c|}{ Nilai } \\
\hline & & 1 & 2 & 3 & 4 \\
\hline 1 & $\begin{array}{l}\text { Kesesuaian antara metode dengan tujuan } \\
\text { pembelajaran }\end{array}$ & - & - & - & $\mathrm{V}$ \\
\hline 2 & Kesesuaian metode dengan materi & - & - & V & - \\
\hline 3 & Metode dapat memotivasi belajar siswa & - & - & $\mathrm{V}$ & - \\
\hline 4 & Metode dapat melibatkan siswa dalam pembelajaran & & & & \\
\hline & Metode dapat mengefektifkan kegiatan pembelajaran & - & - & - & $\mathrm{V}$ \\
\hline 5 & Metode yang digunakan dapat meningkatkan hasil & & & & \\
\hline & belajar siswa & - & - & - & $\mathrm{V}$ \\
\hline 6 & & - & - & - & $\mathrm{V}$ \\
\hline \multicolumn{2}{|c|}{ Jumlah } & 0 & 0 & 6 & 16 \\
\hline \multicolumn{2}{|c|}{ Rata-rata } & \multicolumn{4}{|c|}{3,67} \\
\hline
\end{tabular}

Keterangan score:

$\begin{array}{lll}\text { A } & : 3,28-4,00 & \text { : Sangat Memuaskan } \\ \text { B } & : 2,78-3,27 & \text { : Memuaskan } \\ \text { C } & : 2,38-2,77 & \text { : Kurang }\end{array}$

Dari hasil pengamatan terhadap kemampuan guru dalam menggunakan metode pembelajaran pada pelaksanaan pembelajaran mata pelajaran bahasa Indonesia dengan tujuan agar siswa dapat melengkapi cerita dengan memperhatikan hubungan antara makna kalimat yang satu dengan kalimat lainnya dan siswa dapat menentukan judul yang sesuai berdasarkan gambar seri hasilnya masih dalam kategori "sangat memuaskan" dengan nilai rata-rata 3,67 karena berada dalam interval score yaitu 2,78 - 3,27.

Tabel 5. Hasil Pengamatan Terhadap Kemampuan Guru Kelas V dalam Menggunakan Metode Pembelajaran (Siklus II)

\begin{tabular}{|c|c|c|c|c|c|}
\hline \multirow[t]{2}{*}{ No } & \multirow[t]{2}{*}{ Indikator } & \multicolumn{4}{|c|}{ Nilai } \\
\hline & & 1 & 2 & 3 & 4 \\
\hline 1 & $\begin{array}{l}\text { Kesesuaian antara metode dengan tujuan pembelajaran } \\
\text { Kesesuaian metode dengan materi }\end{array}$ & - & - & - & $\mathrm{V}$ \\
\hline 2 & Metode dapat memotivasi belajar siswa & - & - & $\mathrm{V}$ & - \\
\hline 3 & Metode dapat melibatkan siswa dalam pembelajaran & - & - & - & $\mathrm{V}$ \\
\hline 4 & $\begin{array}{l}\text { Metode dapat mengefektifkan kegiatan pembelajaran } \\
\text { Metode yang digunakan dapat meningkatkan hasil }\end{array}$ & - & - & - & $\mathrm{V}$ \\
\hline 5 & belajar siswa & - & - & $\mathrm{V}$ & - \\
\hline 6 & & - & - & - & V \\
\hline \multicolumn{2}{|c|}{ Jumlah } & $\mathbf{0}$ & 0 & 6 & 16 \\
\hline \multicolumn{2}{|c|}{ Rata-rata } & \multicolumn{4}{|c|}{3,67} \\
\hline
\end{tabular}

$\begin{array}{lll}\text { Keterangan score: } & \\ \mathrm{A} \quad: 3,28-4,00 & \text { : Sangat Memuaskan } \\ \mathrm{B} \quad: 2,78-3,27 & : \text { Memuaskan } \\ \mathrm{C} \quad: 2,38-2,77 & : \text { Kurang }\end{array}$

Mengacu hasil pengamatan terhadap kemampuan guru kelas $\mathrm{V}$ dalam menggunakan metode pembelajaran pada pelaksanaan pembelajaran mata pelajaran bahasa Indonesia, sudah "sangat memuaskan" dengan nilai ratarata 3,67 . 
Tabel 6. Hasil Pengamatan Terhadap Kemampuan Guru Kelas VI dalam Menggunakan Metode Pembelajaran (Siklus II)

\begin{tabular}{|c|c|c|c|c|c|}
\hline \multirow[t]{2}{*}{ No } & \multirow[t]{2}{*}{ Indikator } & \multicolumn{4}{|c|}{ Nilai } \\
\hline & & 1 & 2 & 3 & 4 \\
\hline 1 & $\begin{array}{l}\text { Kesesuaian antara metode dengan tujuan pembelajaran } \\
\text { Kesesuaian metode dengan materi }\end{array}$ & - & - & - & $\mathrm{V}$ \\
\hline 2 & Metode dapat memotivasi belajar siswa & - & - & - & $\mathrm{V}$ \\
\hline 3 & Metode dapat melibatkan siswa dalam pembelajaran & - & - & $\mathrm{V}$ & - \\
\hline 4 & $\begin{array}{l}\text { Metode dapat mengefektifkan kegiatan pembelajaran } \\
\text { Metode yang digunakan dapat meningkatkan hasil }\end{array}$ & - & - & $\mathrm{V}$ & - \\
\hline 5 & belajar siswa & - & - & - & $\mathrm{V}$ \\
\hline \multirow{2}{*}{\multicolumn{2}{|c|}{$\begin{array}{l}\text { 6 } \\
\text { Jumlah }\end{array}$}} & - & - & $\mathrm{V}$ & - \\
\hline & & 0 & 0 & 9 & 12 \\
\hline \multicolumn{2}{|c|}{ Rata-rata } & \multicolumn{4}{|c|}{3,50} \\
\hline
\end{tabular}

\begin{tabular}{lll}
\multicolumn{2}{l}{ Keterangan score: } & \\
$\mathrm{A} \quad: 3,28-4,00$ & : Sangat Memuaskan \\
$\mathrm{B}$ & $: 2,78-3,27$ & $:$ Memuaskan \\
$\mathrm{C}$ & $: 2,38-2,77$ & : Kurang
\end{tabular}

Mengacu hasil pengamatan terhadap kemampuan guru kelas VI dalam menggunakan metode pembelajaran pada pelaksanaan pembelajaran mata pelajaran matematika hasilnya sudah "sangat memuaskan" dengan ratarata skor 3,50 .

\section{Refleksi}

Dari hasil pelaksanaan supervisi klinis pada upaya peningkatan kemampuan guru dalam menggunakan metode pembelajaran diketahui bahwa pada siklus II, guru sudah berusaha untuk meningkatkan kemampuannya dalam mengunakan metode pembelajaran, dan hasilnya sangat memuaskan.

Dari hasil observasi di kelas IV diketahui bahwa guru sudah menerapkan seluruh metode yang terdapat dalam RPP. Selain itu pelaksanaan kegiatan pembelajaran juga sudah menerapkan fasiasi metode sehingga kegiatan pembelajaran yang dilaksanakan lebih maksimal.

Dari hasil observasi di kelas V diketahui bahwa kemampuan guru dalam menguasai metode pembelajaran sudah meninkat dengan hasil perolehan score "sangat memuaskan". Hal itu ditunjukkan dari kemampuan guru melakukan kegiatan pembelajaran dengan tepat dan menerapkan seluruh metode yang ada di RPP sehingga pembelajaran memperoleh hasil yang maksimal.

Dari hasil observasi di kelas VI guru juga sudah mampu menguasai seluruh indikator yang dinilai selama kegiatan supervisi klinis. Metode pembelajaran yang tercantum dalam RPP juga sudah dioptimalkan karena ada satu metode yang terlewat yaitu tugas individual. Selain temuan-temuan tersebut, guru juga sudah melakukan variasi dalam menerapkan metode yang baru yang benar-benar dapat melibatkan siswa secara aktif dalam kegiatan pembelajaran dan mampu memotivasi siswa untuk belajar matematika.

Dari temuan-temuan yang ada, maka pelaksanaan penelitian tindakan sekolah dengan menerapkan supervisi klinis guna meningkatkan kemampuan guru dalam menggunakan alat peraga dapat diakhiri pada siklus II.

\section{PEMBAHASAN}

Pelaksanaan supervisi klinis pada dasarnya difokuskan pada perbalikan pengajaran dengan melalui siklus yang sistematis dari tahap perencanaan, pengamatan, dan analisis intelektual yang Intensif terhadap penampilan mengajar sebenarnya dengan tujuan mengadakan modifikasi rasional.

Berkaitan dengan pelaksanaan kegiatan supervisi klinis di SD Negeri 29 Ganting Kecamatan Bayang Kabupaten Pesisir Selatan, target yang diharapkan adalah kemampuan guru dalam menggunakan metode 
pembelajaran dengan asumsi bahwa melalui penerapan metode yang tepat maka proses ekplorasi, elaborasi dan konfirmasi dalam kegiatan inti pembelajaran dapat dioptimalkan sehingga prestasi belajar siswa menjadi meningkat.

Dasar pertimbangan pengembangan profesionalisme guru pada indikator tersebut karena guru merupakan ujung tombak dalam peningkatan kualitas pembelajaran dan penanam nilai-nilai dasar pada pendidikan sekolah dasar yang selanjutnya akan sangat bermanfaat bagi perkembangan anak didiknya di masa yang akan datang.

Dari hasil pelaksanaan supervise klinis pada studi awal, siklus I, dan siklus II, berikut ini tabel tingkat kemampuan guru dalam menggunakan metode pembelajara berdasarkan persentase indikator yang dikuasai:

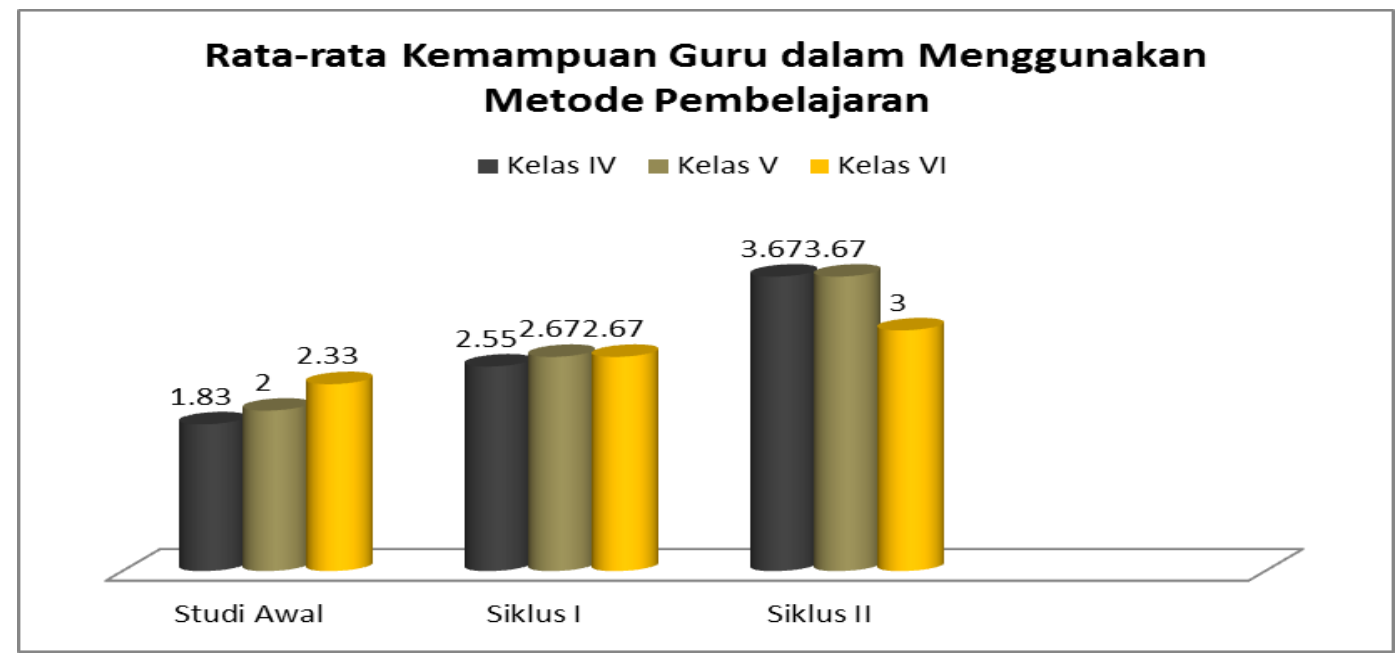

Gambar 1: Persentase Kemampuan Guru dalam Menggunakan Metode Pembelajaran

Melalui pencapaian tersebut, maka tujuan dari supervisi klinis yang antara lain membantu guru mengembangkan kompetensinya, dapat tercapai dengan optimal. Hal tersebut juga dikemukakan oleh guru setelah pelaksanaan observasi, sebagai berikut:

Berkaitan dengan kemampuan guru dalam menggunakan metode pembelajaran, guru kelas IV (Sdri. Susmai Sasrita,S.Pd) menyatakan sebagai berikut:Melalui latihan, bimbingan dan dukungan pada kegiatan supervisi kemampuan kami dalam menggunakan alat peraga menjadi lebih maksimal. (wawancara tanggal 26 Oktober 2017).

Guru kelas V, (Sdri. Jasni,S.Pd.SD), memberikan penyataan berkaitan dengan kemampuan dalam menggunakan metode pembalajaran sebagai berikut: Beberapa indikator yang semula kurang kami pahami, saat ini sudah bisa dipahami dengan baik. Kami juga bisa menerapkan seluruh metode yang sudah tercatat dalam RPP. (wawancara tanggal 27 Oktober 2017).

Dan guru kelas VI, Sdr Asnati, S.Pd.SD memberikan pernyataan tentang kemampuan menyusun RPP sebagai berikut : Beberapa metode baru kami terapkan, dan hal tersebut ternyata hasilnya luar biasa terhadap peningkatan keaktifan dan motivasi siswa untuk belajar. Ini tentu sangat positif karena kelas VI merupakan masa-masa menjelang ujian nasional yang butuh kesungguhan siswa dalam memahami materi. (wawancara tanggal 29 Oktober 2017).

Dari hasil wawancara tersebut, maka secara garis besar melalui kegiatan supervisi klinis diperoleh catatan sebagai berikut: 1) Kemampuan guru dalam menggunakan metode pembelajaran meningkat; 2) Guru lebih menguasai indikator dalam penguasaan metode pembelajaran; 3) Guru dapat memilih metode yang tepat dan sesuai dengan tujuan pembelajaran; 4) Guru lebih terbuka saat mendapatkan permasalahan khususnya dalam penentuan metode pembelajaran.

\section{KESIMPULAN}

Mengacu pada hasil penelitian tindakan sekolah melalui kegiatan supervise klinis, disimpulkan sebagai berikut: 1) Keberhasilan sebuah kegiatan pembelajaran dipengaruhi oleh banyak faktor, baik faktor 
yang dating dari guru, siswa, maupun kepala sekolah sebagai pemimpin di sekolah. Salah satu peranan kepala sekolah dalam kegiatan pembelajaran adalah melakukan upaya perbaikan pembelajaran guru dengan menerapkan pendekatan supervisi, diantaranya supervisi klinis; 2) Metode pembelajaran merupakan salah satu komponen yang sangat mempengaruhi keberhasilan kegiatan belajar mengajar, karena di dalamnya memuat strategi agar anak didik dapat belajar secara efektif dan esifien; 3) Peningkatan kemampuan guru dalam menggunakan metode pembelajaran melalui supervisi klinis merupakan salah satu solusi yang cukup efektif. Hal tersebut dapat dilihat dari hasil akhir penelitian dimana guru dapat menguasai indikator yang ada dalam menentukan metode pembelajaran dan mencari metode yang benar-benar tepat dan sesuai dengan tujuan pembelajaran serta kondisi lingkungan kelas dan lingkungan sekolah itu sendiri yang selanjutnya memberikan manfaat bagi peningkatan prestasi belajar siswa dan peningkatan mutu sekolah.

\section{DAFTAR RUJUKAN}

Abdul Majid, (2005). Perencanaan Pembelajaran. Bandung: Remaja Rosdakarya

Dedi Supriadi, (2002). Laporan Akhir Tahun Bidang Pendidikan dan Kebudayaan. Artikel. Jakarta: Kompas Depdiknas, (2002). Kurikulum dan HAsil Belajar Kompetensi Dasar. Jakarta: Balitbangdiknas

Depdiknas, (2003). Undang-Undang Sistem Pendidikan Nasional. Jakarta: Departemen Pendidikan Nasional Em Zul Fajri dan Ratu Aprilia Senja, (2006. Kamus Lengkap Bahasa Indonesia. Jakarta: Difa Publisher

J. La Solo, (1983). Pendekatan dan Teknik-teknik Supervisi Klinis. Jakarta: Departemen P dan K, Ditjen Pend. Tinggi (PPLPTK)

Nana Sudjana, (2005). Strategi Pembelajaran. Bandung: Alfabeta

Ngalim Purwanto, (2009). Administrasi dan Supervisi Pendidikan. Bandung: Remaja Rosdakarya

Piet A. Sahertian, (2000). Konsep Dasar dan Teknik Supervisi Pendidikan Dalam Rangka Pengambangan Sumber Daya Manusia. Jakarta: Rineka Cipta

Samuel Smith, mengjarkan-matematika-sebuah-pemikiran.html diakses dari http://chamisah.blogspot.com

Syaiful Bahri Djamarah dan Aswan Zain, (2006). Strategi Belajar Mengajar. Jakarta: Rineka Cipta 